\title{
Review:
}

\section{Kajian Pustaka Karakterisasi Perekat Polivinil Asetat Berbasis Air dengan Variabel Surfaktan}

\author{
[Water Base Polyvinyl Acetate Characterization with Surfactant Variable - \\ a Review]
}

\author{
Rony Pasonang Sihombing*, Dieni Nurul Fathiyyah, Nanda Liant Kumara, Agustinus Ngatin \\ Politeknik Negeri Bandung/ Teknik Kimia/ D3 Teknik Kimia
}

\begin{abstract}
Polyvinyl acetate (PVAc) is an applicative polymer used as an adhesive material for one to another. These polymers can be synthesized through an emulsion polymerization process. In the industrial world, the process of making adhesive still involves environmentally unfriendly organic compounds containing xylene, benzene, and toluene. Therefore, water-based adhesive was introduced as an alternative to the PVAc synthesis solution. The aim of this literature review is to identify the type of surfactants used and analyze the PVAc characterization. This literature study focuses on the characterization of water-based PVAc with non-ionic nonylphenol (NP) surfactants including: NP-06, NP-10, NP $10+30$, NP-30 and NP-40. Another surfactant used in this literature study is anionic surfactant Sodium Lauryl Sulfate (SLS) in units of Critical Micelle Concentration (CMC) including $1 \mathrm{CMC}, 3 \mathrm{CMC}, 5 \mathrm{CMC}, 10 \mathrm{CMC}$, and $15 \mathrm{CMC}$. The result is a similarity in phenomena between the two types of surfactants. There is an increase in viscosity and a decrease in the value of the particle size as the surfactant increasing concentration used. However, in terms of the particle size, there is an optimal value where the specific NP surfactant concentration produces specific particle size with grit and at the specific SLS surfactant concentration produces relatively similar particle size.
\end{abstract}

Keyword: Water based adhesive, polyvinyl acetate, surfactant, adhesive viscosity, adhesive viscosity.

Abstrak. Polivinil asetat (PVAc) merupakan salah satu polimer aplikatif yang digunakan sebagai bahan perekat material satu dengan lainnya. Polimer ini dapat disintesis melalui proses polimerisasi emulsi. Dalam dunia industri, proses pembuatan perekat masih melibatkan senyawa organik tidak ramah lingkungan yang mengandung bahan xylena, benzena dan toluena. Oleh karenanya, perekat berbasis air diperkenalkan sebagai alternatif solusi sintesis PVAc. Kajian pustaka ini bertujuan untuk mengidentifikasi jenis surfaktan yang digunakan serta menganalisa karakterisasi dari PVAc yang dihasilkan. Pembuatan kajian pustaka ini menitikberatkan pada karakterisasi PVAc berbasis air dengan surfaktan non-ionik nonylphenol (NP) diantaranya: NP-06, NP-10, NP 10+30, NP-30 dan NP40. Surfaktan lain yang digunakan dalam kajian pustaka ini adalah surfaktan anionik Sodium Lauryl Sulfate (SLS) dalam satuan Critical Micelle Concentration (CMC) diantaranya 1 CMC, 3 CMC, 5 CMC, 10 CMC dan 15 CMC. Hasilnya adalah adanya kesamaan fenomena antara kedua jenis surfaktan tersebut. Terdapat peningkatan viskositas dan penurunan nilai ukuran partikel dalam bertambahnya konsentrasi surfaktan yang digunakan. Namun jika ditinjau dari ukuran partikel, terdapat nilai optimal dimana pada konsentrasi tertentu surfaktan NP menghasilkan nilai ukuran partikel yang relatif stabil dengan kemungkinan adanya grit dan pada konsentrasi tertentu surfaktan SLS menghasilkan nilai ukuran partikel yang besarannya relatif sama.

Kata kunci: Perekat berbasis air, polivinil asetat, surfaktan, viskositas perekat, ukuran partikel perekat.

Diterima: 5 Februari 2021, Disetujui: 24 Maret 2021

Sitasi: Sihombing, R.P., Fathiyyah, D.N., Kumara, N.L., \& Ngatin, A. (2021). Kajian Pustaka Karakterisasi Perekat Polivinil Asetat Berbasis Air dengan Variabel Surfaktan. KOVALEN: Jurnal Riset Kimia, 7(1): 23-29.

\footnotetext{
* Corresponding author

E-mail: rony.pasonang.sihombing@polban.ac.id 
PENDAHULUAN

PVAc nerupakan jenis polimer termoplastis yang jika dipanaskan dapat melunak dan jika didinginkan dapat mengeras/ kaku. Perekat PVAc sangat berkembang di dunia industri Indonesia. Salah satu penggunaannya adalah terdapat pada aplikasi furnitur (Bardak et al., 2017). Namun keterlibatan pelarut organik yang mengandung senyawa xylene, toluene dan benzene dalam sintesis perekat dapat membuat masalah baru. Diantaranya adalah beberapa jenis penyakit yang berpotensi terjadi apabila terhirup maupun tertelan. Penyakit tersebut antara lain leukimia, saluran pernapasan, bronchitis, kerusakan lever atau gagal ginjal (Susilowati, 2011). Disamping itu, polimer perekat yang sudah beredar di pasaran masih mengandung formaldehid sehingga tidak ramah lingkungan (Eskani et al., 2014).

Metode yang sering digunakan dalam mensitesis perekat adalah metode polimerisasi emulsi (Petković et al., 2019; Sudarmaji, 2012). Beberapa cara dapat dilakukan untuk meningkatkan karakteristik PVAc, diantaranya adalah dengan penambahan nanowollastonite (Taghiyari et al., 2020), penambahan starch (Gadhave et al., 2018), nanomaterial asam sitrat (Roto et al., 2020), nanofibril selulosa (Chaabouni \& Boufi, 2017). Polimerisasi emulsi PVAc berbasis air dapat menjadi alternatif pembuatan perekat yang lebih ramah lingkungan. Proses ini relatif aman dan mudah karena jumlah ketersediaan air sangat melimpah dan mudah ditemukan. Secara umum, polimerisasi PVAc merupakan cairan putih susu dengan kandungan $40-60 \%$ polimer padat, sisanya adalah air, protektif koloid, surfaktan dan aditif lainnya (Berber, 2013).
Surfaktan dicirikan oleh keberadaan dua gugus dengan derajat polaritas berbeda pada unit molekul yang sama (Azarmi \& Ashjaran, 2015). Dengan adanya kedua bagian berbeda tersebut, surfaktan memberi sifat khusus terhadap media yang berbeda. Surfaktan memiliki kemampuan untuk menyerap di berbagai jenis permukaan atau antarmuka (Olkowska et al., 2014). Sifat penting lain dari surfaktan adalah kemamppuan senyawa tersebut dalam larutan yang cenderung untuk membentuk misel (Olkowska et al., 2013). Apabila konsentrasi surfaktan meningkat dalam air, molekul surfaktan membentuk misel dan bagian dalam hidrofobik, misel menciptakan lingkungan non-polar (Azarmi \& Ashjaran, 2015). Oleh karenanya, sifat spesifik tersebut membuat surfaktan memiliki fungsi yang beragam dalam memberi kestabilan dan diterapkan di berbagai bidang aktivitas manusia. Berdasarkan gugus hidrofiliknya, kelompok surfaktan terdiri dari anionik, kationik, non-ionik dan zwitter ionik. Surfaktan jenis non ionik dan anionik adalah surfaktan yang paling efektif dan banyak digunakan dalam polimerisasi emulsi (J, 2009). Salah satu contoh jenis surfaktan non-ionik yang banyak digunakan adalah nonylphenol (NP) (Sharma et al., 2018), sedangkan jenis surfaktan anionik yang sering digunakan adalah Sodium Lauryl Sulfate (SLS) (Berber, 2013).

Pada polimerisasi emulsi, viskositas bergantung pada banyaknya polimer yang terbentuk dan jenis polimer yang didapatkan (Helmiyati et al., 2010). Viskositas merupakan salah satu karakteristik polimer PVAc dimana hal ini menunjukkan kekentalan dan kemampuan emulsi dalam mengalir. Kemampuan ini merupakan salah satu karakteristik yang penting. Viskositas memiliki 
hubungan yang erat dengan stabilitas emulsi. Semakin kental suatu emulsi maka semakin tinggi pula tingkat stabilitasnya (Raymundo et al., 2002).

Kajian pustaka ini menggunakan sistem studi literatur dengan mengacu pada referensireferensi penelitian sejenis dengan surfaktan nonylphenol dan surfaktan SLS sebagai variabelnya. Jenis data studi literatur yang sudah didapat dianalisis dengan metode analisis deskriptif dengan cara mendeskripsikan fakta-fakta yang kemudian disusul dengan analisis.

Dalam pendalaman kajian pustaka, penelitian sejenis sebelumnya dengan fokus penggunaan surfaktan non-ionik NP dan surfaktan anionik SLS terhadap karakterisasi PVAc telah dirangkum pada Tabel 1 dimana referensi-referensi tersebut merupakan penelitian-penelitian yang dipublikasikan dalam kurun waktu paling lama 13 tahun terakhir.

\section{Pengaruh Konsentrasi Surfaktan Nonylphenol terhadap Viskositas}

NP merupakan salah satu surfaktan nonionik. Viskositas polimer akan meningkat dengan penambahan konsentrasi cairan polimer dan penambahan surfaktan non-ionik rantai panjang (Berber et al., 2018; Sarac \& Yildirim, 2008; Sihombing \& Ngatin, 2019).

Tabel 1. Rangkuman penelitian sejenis terkait PVAc dan surfaktan

\begin{tabular}{|c|c|c|c|}
\hline No & Metode & Ringkasan yang diteliti & Artikel \\
\hline 1 & $\begin{array}{l}\text { Seeding, } \\
\text { feeding }\end{array}$ & $\begin{array}{l}\text { Pengaruh kecepatan pengadukan, dropping monomer dan } \\
\text { inisiator, serta konsentrasi butil akrilat yang ditambahkan } \\
\text { terhadap viskositas. }\end{array}$ & $\begin{array}{l}\text { (Tunjungsari \& } \\
\text { Sumarni, 2019) }\end{array}$ \\
\hline 2 & $\begin{array}{l}\text { Seeding, } \\
\text { feeding }\end{array}$ & $\begin{array}{l}\text { Pengaruh variasi surfaktan NP-06 dan NP-10 terhadap } \\
\text { viskositas PVAc. }\end{array}$ & $\begin{array}{l}\text { (Sihombing \& } \\
\text { Ngatin, 2019) }\end{array}$ \\
\hline 3 & $\begin{array}{l}\text { Seeding, } \\
\text { feeding }\end{array}$ & $\begin{array}{l}\text { Pengaruh variasi konsentrasi masing-masing surfaktan NP- } \\
06 \text { dan NP-10 terhadap viskositas PVAc. }\end{array}$ & $\begin{array}{l}\text { (Sihombing et al., } \\
\text { 2020) }\end{array}$ \\
\hline 4 & Semikontinu & Pengaruh surfaktan dan inisiator terhadap sifat lateks. & $\begin{array}{l}\text { (Berber et al., } \\
\text { 2018) }\end{array}$ \\
\hline 5 & $\begin{array}{l}\text { Seeding, } \\
\text { feeding }\end{array}$ & $\begin{array}{l}\text { Pengaruh variasi konsentrasi SLS dan LDBS dan variasi } \\
\text { konsentrasi inisiator APS dan KPS terhadap viskositas dan } \\
\text { ukuran partikel. }\end{array}$ & (Sudarmaji, 2012) \\
\hline 6 & $\begin{array}{l}\text { Semikontinu, } \\
\text { batch dan } \\
\text { seeding }\end{array}$ & $\begin{array}{l}\text { Pengaruh variasi konsentrasi SLS (2 CMC, } 5 \text { CMC, } 10 \\
\text { CMC dan } 20 \text { CMC) dan variasi konsentrasi inisiator APS } \\
(1 \%, 2 \%, 3 \%) \text { terhadap ukuran partikel. }\end{array}$ & $\begin{array}{l}\text { (Helmiyati et al., } \\
\text { 2010) }\end{array}$ \\
\hline 7 & $\begin{array}{l}\text { Semikontinu, } \\
\text { batch dan } \\
\text { seeding }\end{array}$ & $\begin{array}{l}\text { Pengaruh variasi konsentrasi surfaktan SLS ( } 0.5 \mathrm{CMC}, 1 \\
\mathrm{CMC}, 3 \mathrm{CMC}, 5 \mathrm{CMC}) \text { dan variasi konsentrasi inisiator APS } \\
(0.1 \%, 0.5 \%, 1 \% \text { berat monomer) terhadap viskositas dan } \\
\text { ukuran partikel. }\end{array}$ & (Utami, 2008) \\
\hline 8 & Semikontinu & $\begin{array}{l}\text { Pengaruh surfaktan terhadap sifat fisikokimia (konversi, } \\
\text { viskositas, berat molekul) }\end{array}$ & $\begin{array}{l}\text { (Sarac \& Yildirim, } \\
\text { 2008) }\end{array}$ \\
\hline
\end{tabular}

Campuran NP-10 dan NP-30 dengan rasio (w/w) digunakan untuk mengetahui pengaruh konsentrasi surfaktan terhadap viskositas pada penelitian sebelumnya. Pemberian campuran surfaktan (NP30/NP10; $50 / 50$ ) dilakukan dengan konsentrasi 0\%, 25\% 
dan 33\%. Hasilnya menjelaskan bahwa produk polimer stabil dan konversi monomer terbanyak pada konsentrasi surfaktan $25 \%$. Grafik tren pengaruh variasi konsentrasi terhadap viskositas disajikan pada Gambar 1.

Nilai persen konversi yang tinggi menandakan tingginya kandungan padatan didalam larutan sehingga nilai viskositas akan meningkat. Berdasarkan Gambar 1, terlihat bahwa semakin besar konsentrasi NP maka nilai viskositas yang dihasilkan juga semakin tinggi. Hal ini dapat dilihat pada penelitian pendahulu dengan hasil sebesar $103 \mathrm{Cp}, 128$ Cp dan 146Cp (Berber et al., 2018; Sarac \& Yildirim, 2008; Sihombing \& Ngatin, 2019). Namun pada batas tertentu, ada kemungkinan perubahan kenaikan grafik yang lebih curam. Hal ini dikarenakan ada terbentuknya grit pada akhir polimer. Sedangkan grit adalah hal yang perlu diminimalkan sehingga kondisi optimum proses tersebut berada di kandungan surfaktan sebanyak $25 \%$.

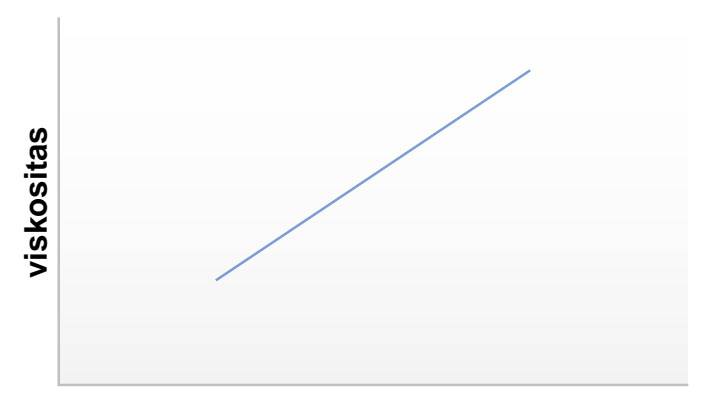

konsentrasi surfaktan NP

Gambar 1. Tren pengaruh konsentrasi surfaktan NP terhadap viskositas

Pada penelitian lain, disebutkan bahwa surfaktan yang digunakan adalah NP-6, NP-10, NP-10+30 dan NP-40 (Sarac \& Yildirim, 2008; Sihombing et al., 2020; Sihombing \& Ngatin, 2019). Pada penelitian lain, dengan variasi panjang rantai surfaktan, didapatkan juga hasil yang sama seperti pada Gambar 1 .
Berdasarkan fenomena ini dapat disimpulkan bahwa semakin besar nomor surfaktan, semakin panjang rantai polimer yang dihasilkan. Sehingga semakin besar molekul polimer tersebut dan nilai viskositasnya dapat meningkat (Syahputra \& Suhartini, 2014).

\section{Pengaruh Konsentrasi Surfaktan Nonylphenol terhadap Ukuran Partikel}

Besarnya konsentrasi surfaktan merupakan salah satu faktor yang mempengaruhi besar kecilnya ukuran partikel dari suatu polimer. Semakin besar konsentrasi surfaktan NP, maka ukuran partikel yang dihasilkan semakin kecil (Utami, 2008). Hal ini disebabkan karena semakin besar konsentrasi surfaktan, jumlah misel yang terbentuk semakin banyak. Untuk mengetahui tren pengaruh konsentrasi surfaktan NP terhadap ukuran partikel, penelitian sebelumnya menggunakan variasi konsentrasi 33\%, 25\% dan 0\% (Berber et al., 2018). Tren pengaruh tersebut disajikan pada Gambar 2.

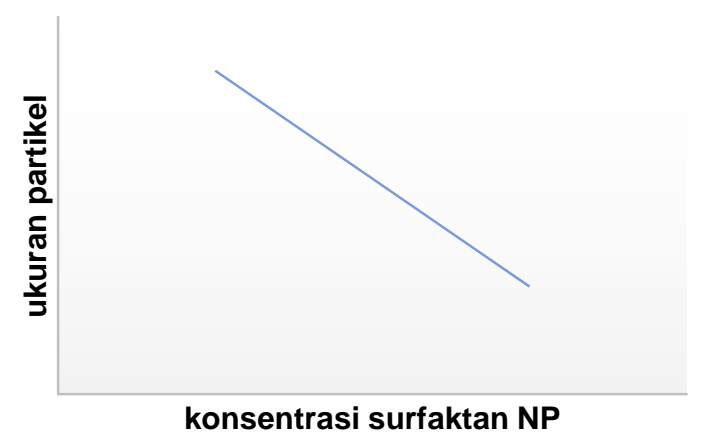

Gambar 2. Tren pengaruh konsentrasi surfaktan NP terhadap ukuran partikel

Pada penelitian sebelumnya, saat konsentrasi $0 \%$, diperoleh ukuran partikel yang cukup tinggi (sebesar $482 \mathrm{~nm}$ ). Lalu pada konsentrasi $25 \%$ ukuran partikel menurun hingga mencapai $221 \mathrm{~nm}$ (Sarac \& Yildirim, 2008). Hal ini telah membuktikan bahwa teori 
sebanding dengan praktiknya. Namun pada konsentrasi tertentu, ukuran partikel dapat menjadi tidak konsisten. Hal ini disebabkan oleh faktor belum sempurnanya reaksi polimerisasi serta adanya monomer sisa yang tidak bereaksi dengan sempurna menjadi polimer (Tunjungsari \& Sumarni, 2019).

\section{Pengaruh Konsentrasi Surfaktan SLS terhadap Viskositas Polimer}

Faktor yang mempengaruhi viskositas ialah suhu, berat molekul, tekanan konsentrasi (Lumbantoruan \& Yulianti, 2016). Pada jenis konsentrasi SLS, variasi konsentrasi yang digunakan adalah unit CMC. Tren hasil penelitian sebelumnya dengan menggunakan surfaktan SLS dapat dilihat pada Gambar 3.

Terdapat fenomena peningkatan viskositas dengan bertambahnya konsentrasi surfaktan (Gambar 3). Hal ini dikarenakan dengan bertambahnya konsentrasi surfaktan SLS, ukuran partikel semakin kecil dan jarak antar partikel semakin rapat, sehingga menyebabkan viskositas semakin meningkat.

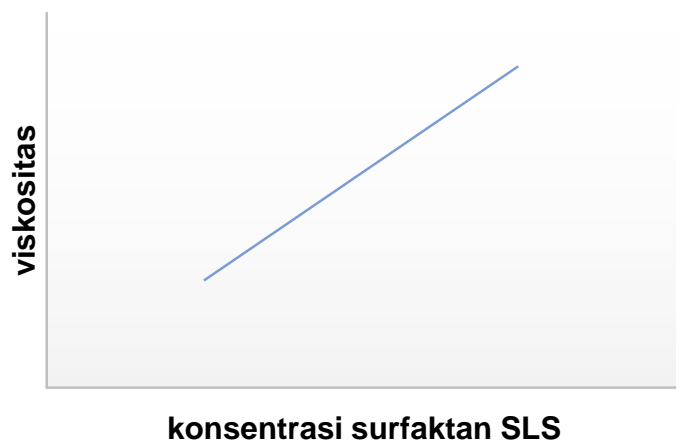

Gambar 3.Tren pengaruh konsentrasi surfaktan SLS terhadap viskositas

\section{Pengaruh Konsentrasi Surfaktan SLS terhadap Ukuran Partikel}

Viskositas polimer emulsi dipengaruhi oleh ukuran partikel polimer dan jumlah gugus fungsional yang berinteraksi dengan molekul lain (Joseph, 2019). Pada penelitian sebelumnya, variasi konsentrasi surfaktan SLS yang digunakan adalah $0.5 \mathrm{CMC}, 1 \mathrm{CMC}, 5$ CMC, 10 CMC dan 20 CMC dengan menggunakan teknik semikontinu serta waktu feeding 5 jam (Helmiyati et al., 2010). Tren hasil penelitian ditunjukkan pada Gambar 4.

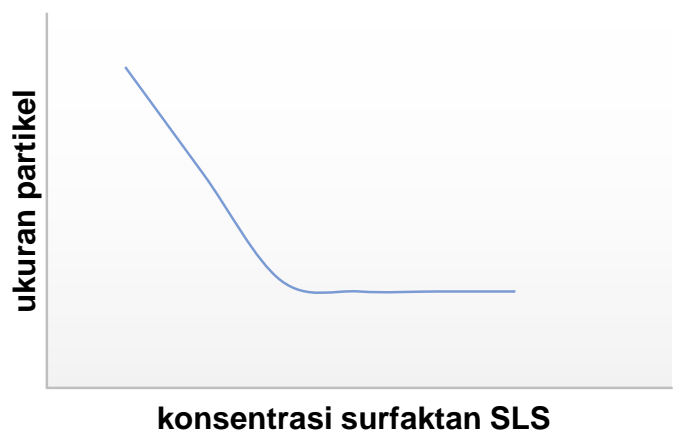

Gambar 4. Tren Pengaruh konsentrasi surfaktan SLS terhadap ukuran partikel

Secara umum, berdasarkan Gambar 4 terjadi penurunan ukuran partikel. Ini dikarenakan semakin besar konsentrasi surfaktan SLS, semakin kecil ukuran partikel yang dihasilkan. Namun jika dilihat dari tingkat efektifitasnya, pada nilai tertentu, terdapat kestabilan ukuran partikel yang dihasilkan. Sehingga ini dapat digunakan sebagai titik optimal penggunaan besaran konsentrasi surfaktan SLS.

\section{KESIMPULAN}

Dari hasil studi literatur, dapat diambil kesimpulan bahwa baik penggunaan surfaktan non-ionik (NP) dan anionik (SLS) menghasilkan fenomena yang relatif sama. Diantaranya adalah peningkatan nilai viskositas dan penurunan nilai ukuran partikel jika konsentrasinya ditingkatkan. Namun jika ditinjau dari penurunan ukuran partikel, ada nilai optimum yang dapat digunakan dalam pengembangan untuk penelitian-penelitian sejenis berikutnya. 


\section{DAFTAR PUSTAKA}

Azarmi, R., \& Ashjaran, A. (2015). Type and application of some common surfactants. Journal of Chemical and Pharmaceutical Research, 7(2), 632-640.

Bardak, T., Tankut, A. N., Tankut, N., Aydemir, D., \& Sozen, E. (2017). The bending and tension strength of furniture joints bonded with polyvinyl acetate nanocomposites. Maderas: Ciencia y Tecnologia, 19(1), 51-62.

Berber, H. (2013). Emulsion Polymerization: Effects of Polymerization Variables on the Properties of Vinyl Acetate Based Emulsion Polymers. Polymer Science. https://doi.org/10.5772/51498

Berber, H., Tamer, Y., \& Yildirim, H. (2018). The effects of feeding ratio on final properties of vinyl acetate-based latexes via semicontinuous emulsion copolymerization. Colloid and Polymer Science, 296(1), 211-221.

Chaabouni, O., \& Boufi, S. (2017). Cellulose nanofibrils/polyvinyl acetate nanocomposite adhesives with improved mechanical properties. Carbohydrate Polymers, 156, 64-70.

Eskani, I. N., Widiastuti, R., \& Lathifah, N. N. (2014). Karakterisasi perekat alami dari tumbuhan untuk industri kerajinan. Seminar Nasional Teknologi Industri Hijau 2, May 2017, 295-300.

Gadhave, R. V., Mahanwar, P. A., \& Gadekar, P. T. (2018). Starch stabilized polyvinyl acetate emulsion: Review. Polymers from Renewable Resources, 9(2), 75-84.

Helmiyati, Budianto, E., \& Arinda, N. (2010). Polimerisasi Emulsi Etil Akrilat: Pengaruh Konsentrasi Surfaktan, Inisiator Dan Teknik Polimerisasi Terhadap Distribusi Ukuran Partikel. Makara Journal of Science, 13(1), 59-64.

J, G. (2009). Colloids and Interfaces with Surfactants and Polymers [Goodwin_J.] (BookFi.org) (second). a john wiley and sons, Ltd,

Joseph Baskoro Sanaji. (2019). Pengaruh Konsentrasi Tween 80 Sebagai Surfaktan
Terhadap Karakteristik Fisik Sediaan Nanoemulgel Ibuprofen. 6(2).

Lumbantoruan, P., \& Yulianti, E. (2016). Pengaruh Suhu Terhadap Viskositas Minyak Pelumas (Oli). Jurnal Sainmatika, 13(2), 26-34.

Olkowska, E., Ruman, M., Kowalska, A., \& Polkowska, Z. (2013). Determination of surfactants in environmental samples. part ii. anionic compounds. Ecological Chemistry and Engineering S, 20(2), 331342.

Olkowska, E., Ruman, M., \& Polkowska, Z. (2014). Occurrence of surface active agents in the environment. Journal of Analytical Methods in Chemistry, 2014. https://doi.org/10.1155/2014/769708

Petković, G., Vukoje, M., Bota, J., \& Preprotić, S. P. (2019). Enhancement of polyvinyl acetate (PVAc) adhesion performance by $\mathrm{SiO} 2$ and $\mathrm{TiO} 2$ nanoparticles. Coatings, 9(11), 1-17. https://doi.org/10.3390/coatings9110707

Raymundo, A., Franco, J. M., Empis, J., \& Sousa, I. (2002). Optimization of the composition of low-fat oil-in-water emulsions stabilized by white lupin protein. JAOCS, Journal of the American Oil Chemists' Society, 79(8), 783-790.

Roto, R., Rianjanu, A., Rahmawati, A., Fatyadi, I. A., Yulianto, N., Majid, N., Syamsu, I., Wasisto, H. S., \& Triyana, K. (2020). Quartz Crystal Microbalances Functionalized with Citric Acid-Doped Polyvinyl Acetate Nanofibers for Ammonia Sensing. ACS Applied Nano Materials, 3(6), 5687-5697. https://doi.org/10.1021/acsanm.0c00896

Sarac, A., \& Yildirim, H. (2008). Semicontinuous emulsion copolymerization of vinyl acetate and butyl acrylate using a new protective colloid. Part 1. Effect of different emulsifiers. Polymers for Advanced Technologies, November 2007, 229-236. https://doi.org/10.1002/pat

Sharma, M., Chadha, P., \& Madhu Sharma, C. (2018). Toxicity of non-ionic surfactant 4nonylphenol an endocrine disruptor: $A$ 
review. $190 \sim$ International Journal of Fisheries and Aquatic Studies, 6(2), 190197. www.fisheriesjournal.com

Sihombing, R. P., \& Ngatin, A. (2019). Modifikasi Homopolimer Poli (Vinil Asetat) dengan Variabel Hidrofobisitas Emulsifier untuk Aplikasi Perkayuan. Fluida, 12(2), 72-77.

https://doi.org/10.35313/fluida.v12i2.1620

Sihombing, R. P., Sudarman, R., \& Ngatin, A. (2020). Pengaruh Konsentrasi Surfaktan Non-lonik Terhadap Viskositas Perekat Polivinil Asetat Berbasis Air. KOVALEN: Jurnal Riset Kimia, 6(3), 165-170.

Sudarmaji. (2012). Mempelajari pengaruh jenis inisiator, jenis surfaktan dan waktu feeding monomer terhadap kinerja pressure sensitive adhesive berbasis air.

Susilowati, B. (2011). Resiko Kesehtan Terhadap Pajanan Benzene Pada Pekerja Industri Sepatu Kulit di PIK Pulogadung Tahun 2011.

Syahputra, A. ., \& Suhartini, M. (2014). Peningkatan Stabilitas Viskositas Pelmuas Hidrolik dari Kopolimer Lateks Karet alam-Stirena. Jurnal IImu-IImu Hayati Dan Fisik, 15(1), 60-64.

Taghiyari, H. R., Esmailpour, A., Adamopoulos, S., Zereshki, K., \& Hosseinpourpia, R. (2020). Shear strength of heat-treated solid wood bonded with polyvinyl-acetate reinforced by nanowollastonite. Wood Research, 65(2), 183-194.

Tunjungsari, F., \& Sumarni, W. (2019). Indonesian Journal of Chemical Science Karakteristik Adhesive Polymer Polivinil Asetat Termodifikasi Butil Akrilat untuk Aplikasi Transfer Metalize. Idonesian Journal of Chemical Science, 8(2).

Utami, R. T. (2008). Pengaruh Konsentrasi Surfaktan Sodium Lauryl Sulfate (SIs), Inisiator Ammonium Peroxodisulfate (Aps) Dan Teknik Polimerisasi Terhadap Ukuran Dan Distribusi Ukuran Partikel Pada Homopolimerisasi Butil Akrilat. Journal of Chemical Information and Modeling, 53(9), 1689-1699. 